\title{
ATYPICAL TOPOGRAPHY OF THE INTERNAL FEMALE GENITAL ORGANS IN A 7 MONTH OLD FETUS
}

\author{
D.V.Proniaiev, F.D.Marchuk, T.V.Khmara \\ Department of Anatomy, Topographic Anatomy and Operative Surgery (Head-Prof. Yu.T.Akhtemiichuk), \\ Human Anatomy (Head - Prof. B.H.Makar) of Bukovinian State Medical University, City of Chernivtsi
}

\section{АТИПОВА ТОПОГРАФІЯ ЖІНОЧИХ ВНУТРІШНІХ СТАТЕВИХ ОРГАНІВ ПЛОДА 7 МІСЯЦІВ}

Резюме. При дослідженні семимісячного плода жіночої статі виявлено рідкісний варіант топографії внутрішніх статевих органів та кровоносних судин таза. Описані особливості форми та синтопії яєчників, маткових труб, наведені морфометричні параметри загальної, зовнішньої та внутрішньої клубових артерій.

Ключові слова: яєчник, матка, маткова труба, плід, людина.

While studying a seven-month old fetus of the female sex a rare variant of the topography of the internal genital organs and the blood vessels of the pelvis has been detected. The specific characteristics of the form and syntopy of the ovaries, uterine tubes have been described, the morphometric parameters of the common, external and internal iliac arteries have been presented. A research of the consistent patterns of the forming of the structure and topography of a fetus is of great importance for understanding the mechanisms of the form-building of organs [1-3].

While investigating a fetus, measuring 260 $\mathrm{mm}$ of the parietococcygeal length (PCL) a rare variant of the topography of the internal female genital organs was detected by us (the Figure). Thus, the right ovary was located in the cavity of the large pelvis close to the right inguinal ligament, whereas the left ovary is lower than the right one, at the level of the terminal line. The circumference of the pelvis at the level of the iliac crest made up $190.0 \mathrm{~mm}$. The right ovary of an elongated trihedral form is located obliquely. One could identify the following structures in the ovary: the posterior, anterosuperior and posteroinferior surfaces; the superior, inferior (free), and anterior (the mesovarial) margins; the tubal and uterine extremities. The uterine (pointed) extremity closely adjoined the posterior surface of the uterine body in front and the rectum behind. The tubal end of the ovary in the form of a hook adjoined the fimbriae of the infundibulum of the uterine tube. The right external iliac artery and the ureter extend behind the uterine end. The ovarian length made up $15.0 \mathrm{~mm}$, the width $-5.0 \mathrm{~mm}$, the thickness (in the middle part) $-3.5 \mathrm{~mm}$. The suspensory ligament of the ovary was attached to the inferiomargin of the ovary at a distance of $4 \mathrm{~mm}$ from the apex of its tubal end. The ligamentum ovarii proprium, $2 \mathrm{~mm}$ in length was attached to the posterior surface of the uterine body below the uterine tube. The length of the mesovarium $-10.0 \mathrm{~mm}$, the width $-1.5 \mathrm{~mm}$. The ampulla of the uterine tube adjoined the anterosuperior surface of the ovary. The total length of the right uterine tube constituted $21.0 \mathrm{~mm}$ : the isthmus $-5 \mathrm{~mm}$, the ampulla $-10.0 \mathrm{~mm}$, the infundibulum $-5 \mathrm{~mm}$. the ampulla of the uterine tube in the form of three loops abutted on the right umbilical artery whose external diameter made up $4.1 \mathrm{~mm}$. The isthmus of the uterine tube is to be found over the superior margin of the ovary. The parietal peritoneum passes on from the greater transverse muscle to the right uterine tube, covering it on all sides and continues into the mesovarium.

The left ovary of an elongated irregular trihedral form was located horizontally. One could differentiate the following structures in the ovary: superior, anterior and posterior surfaces; the superior inferior and anterior (mesovarial) margins; the 


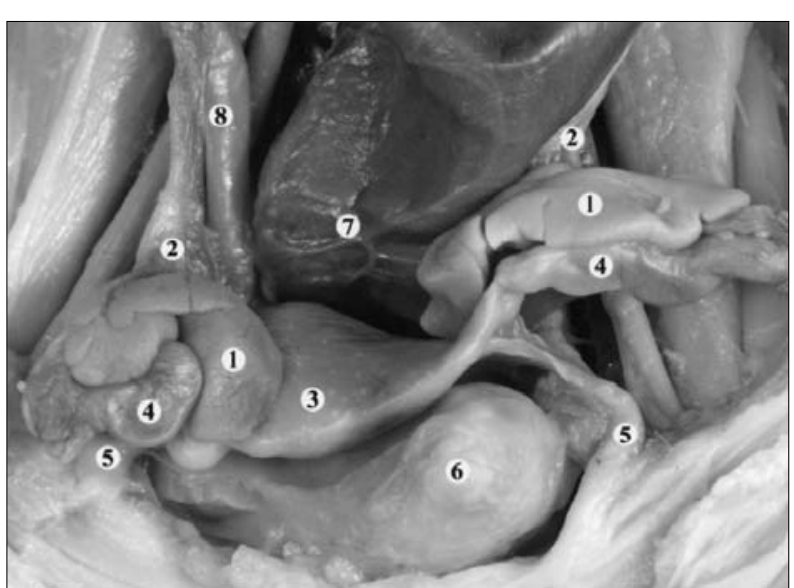

Figure. The internal female genital organs of a fetus $265 \mathrm{~mm}$ of PCL. Macrospecimen. A x 1,5 magnification: 1 - the ovaries; 2 - the external iliac arteries; 3 - the uterus; 4 - the uterine tubes; 5 - the round ligaments of the uterus; 6 - the urinary bladder; 7 - the rectum; 8 - the right ureter.

uterine and tubal ends. The uterine (rounded) ends of the ovary were identified below the terminal line behind the uterine body, whereas its apex touched the lateral wall of the rectum. The tubal end of the ovary (rounded) located at the level of the spinal line adjoined the fimbriae of the infundibulum of the left uterine tube. The left external iliac artery was located behind the ovary, whereas the left ureter was to be found more medially from the latter. The suspensory ligament of the ovary was attached to the lateral margin of the mesovarium. The ligamentum ovarii proprium, $2.9 \mathrm{~mm}$ in length, was attached to the posterior surface of the uterine body below the uterine tube. The length of the left ovary makes up $9 \mathrm{~mm}$, the width $-2.0 \mathrm{~mm}$; the ovarian length is $14.5 \mathrm{~mm}$ the width is $5 \mathrm{~mm}$, the thickness is $2.1 \mathrm{~mm}$. The left uterine tube is characterized by an S-like form. The total length of the uterine tube made up $19.2 \mathrm{~mm}$ : the isthmus $4.0 \mathrm{~mm}$, the ampulla $-8.2 \mathrm{~mm}$ and the infundibulum $-5.0 \mathrm{~mm}$. The fundus and the upper part of the uterine body were identified in the cavity of the large pelvis, whereas the lower part of the uterine body and neck - in the cavity of the pelvis minor. The distance between the uterine tubes made up 4.0 $\mathrm{mm}$ at the level of the uterine fundus.

Thus, this particular research is indicative of broad polymorphism of the internal female genital organs during the perinatal period. An in-depth research of the perinatal anatomy of the human organs and systems will improve considerably the quality of prognosticating the risks of congenital malformations $[4,5]$.

\section{Bibliography}

1. Ахтемийчук Ю.Т. Исследование закономерностей морфометрических параметров органов и структур в перинатальном периоде онтогенеза / Ю.Т.Ахтемийчук, А.Н.Слободян, Д.В.Проняев [и др.] // Функи. морфология человека и животных: матер. Х конгр. Ассоциации морфологов (г. Ярославль, 29-30.09.2010 г.) // Морфол. - 2010. T. 137, № 4. - С. 22. 2. Марчук В.Ф. Синтопія яєчників у плода людини 4-місяців / В.Ф.Марчук, О.В.Дибель, Ю.Ф.Марчук // Від фундаментальних досліджень - до прогресу в медицині: матер. наук.-практ. конф. з міжнар. участю, присв. 200річчю з дня заснування Харківського держ. мед. ун-ту (Харків, 17-18 січня 2005 р.). - Харків, 2005. - С. 6. 3. Нариси перинатальної анатомії / [Ю.Т.Ахтемійчук, О.М.Слободян, Т.В.Хмара та ін.]; за ред. Ю.Т.Ахтемійчука. - Чернівці: БДМУ, 2011. - 300 с. 4. Ахтемійчук Ю.Т. Актуальність анатомічних досліджень у перинатальному періоді онтогенезу / Ю.Т.Ахтемійчук // Перинатальна охорона плода: проблеми, наслідки, перспективи: матер. наук.-практ. конф. з міжнар участю (Чернівці, 14 квітня 2011 р.). - Чернівці: Медуніверситет, 2011. - С. 7-12. 5. П'ятницька Т.А. Гістотопографія маткових труб у 10-місячних плодів / Т.А.П'ятницька // Анатомо-хірургічні аспекти дитячої гастроентерологї: матер. 2-го наук. симп. (Чернівиі, 21 травня 2010 р.); за ред. проф. Ю.Т.Ахтемійчука. - Чернівці, 2010. - С. 98-99.

\section{АТИПИЧНАЯ ТОПОГРАФИЯ ЖЕНСКИХ ВНУТРЕННИХ ПОЛОВЫХ ОРГАНОВ ПЛОДА 7 МЕСЯЦЕВ}

Резюме. При исследовании семимесячного плода женского пола обнаружено редкий вариант топографии внутренних половых органов и кровеносных сосудов таза. Описаны особенности формы и синтопии яичников, маточных труб, приведены морфометрические параметры общей, внешней и внутренней подвздошных артерий.

Ключевые слова: яичник, матка, маточная труба, плод, человек.

\section{ATYPICAL TOPOGRAPHY OF THE INTERNAL FEMALE GENITAL ORGANS IN A 7 MONTH OLD FETUS}

Abstract. While studying a female 7-month old fetus a rare variant of the topography of the internal organs and blood vessels of the pelvis were detected. The peculiar features of the form and syntopy of the ovaries, uterine tubes have been described. The morphometric parameters of the common, external and internal iliac arteries have been adduced.

Key words: ovary, uterus, uterine tube, fetus, human.

Bukovinian State Medical University (Chernivtsi)

Надійшла 02.06.2011 p. Рецензент - д. мед. н. Ю.Я.Кривко (Львів) 